\title{
調味食品研究宝巡り (三)
}

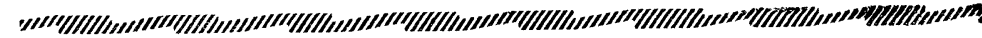

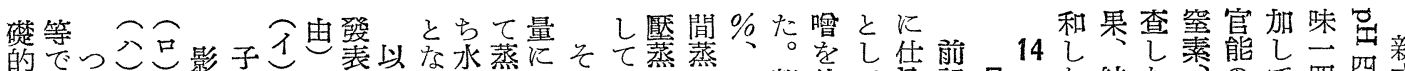

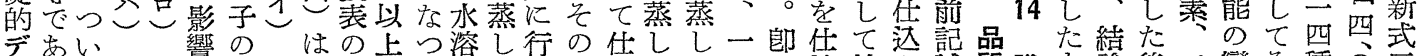

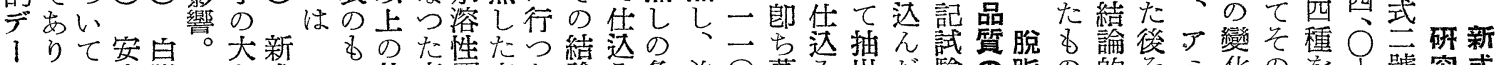

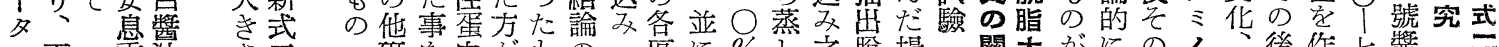

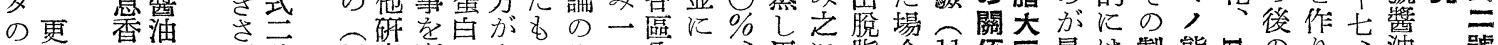

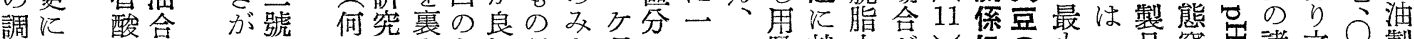

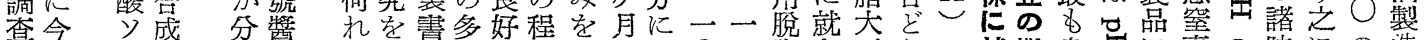

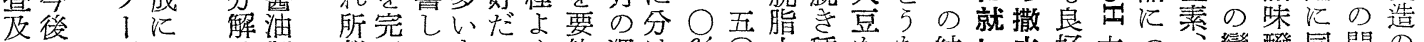

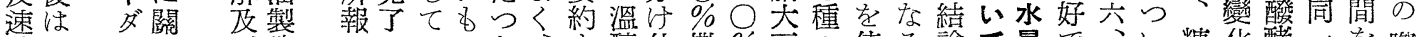

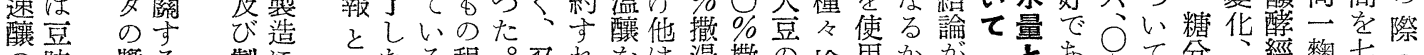
品醬る 製氾 問噌 油 蜜際 題溜防险没原

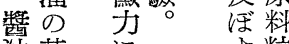
泬基泟守粒

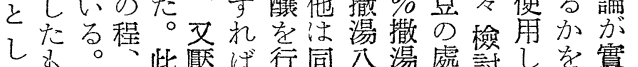

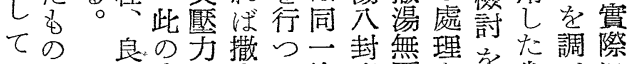

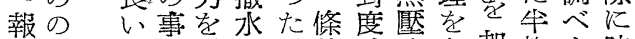
告中製は掛は。件公七加䴹よ味

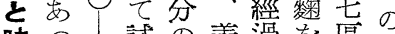
味つ五試の差過を區中 噌た吾驗變色篦同分中 手。五し化度知樣し和

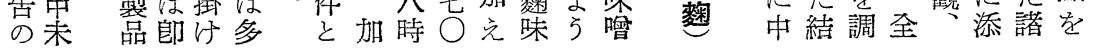

農 日の卒た御か

$\tau$ で

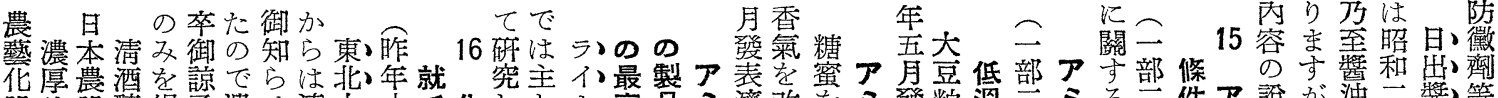

內り汅は防

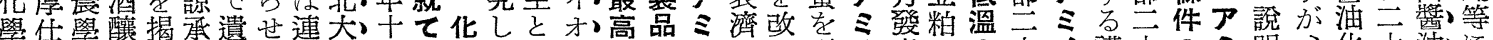
會达大造げい憾は絡學。一 東に會過るたな少の農月月 北於に程とぶがく手學、日 支忊てに次きら清違部。本 部る發於の度大酒い農農 第酵袁恀通い部にで業藝 百母再分分閵い微华

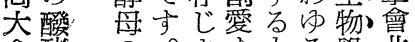
會酵の。委守名る學北

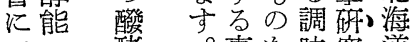
て合酵事を味究道 發昭能參に永食窒索 表和 昭考致屆品部

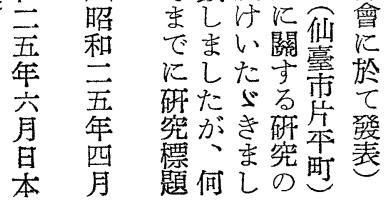

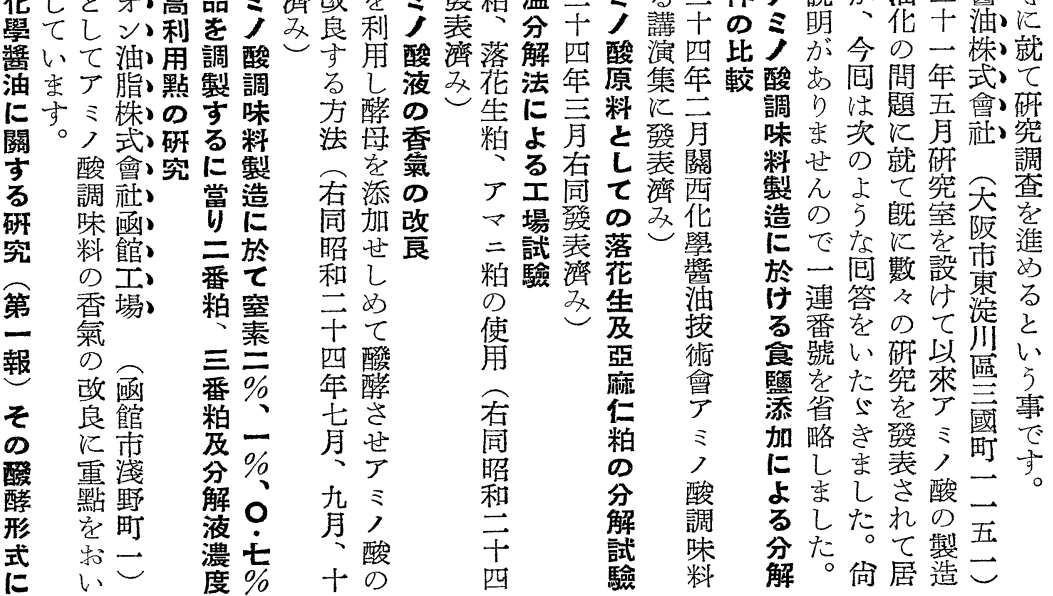

事感の八27 弱

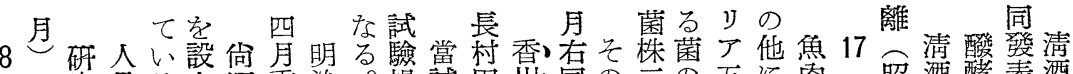

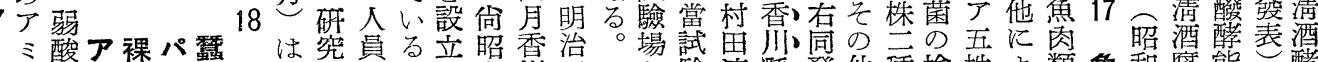
寸後銺種絲ノにミ朲ン豆小次題は。し和川四

。油油狀酸よ广脫酵を桀の目技

趜味絲菌分方酸脂母單の涌つ師

武噌狀の解前の䂃の用みり自五 製の菌硎處硎芽培すに

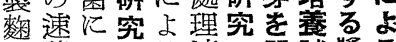

裝醇つ䔬つ液單試醬る

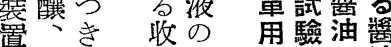

試南絲

驗一油年

場年試四

和、々十驗月

立主 拹二場香

の酱々

改油の営汍

善の洪 質母

它防粉 の液

の徽胥查と

他蛋查乙

の研自

䣷究分

究等解

行の 年

5 試處

そ 驗理

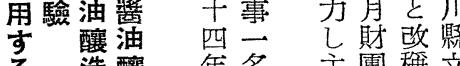

る造釀年名

醬試造

油驗試

月 雇

至負

至照

和一製离旁。と

三名䔏業な

吾名 究學照

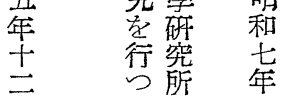

と驗清縣墢他種檢株上類魚和腐能酵 し場濠嶈表絲を索をるよ肉二造の母

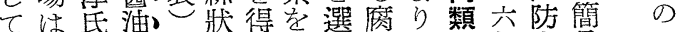
創明の試等菌た行擇敗腐の年止易コ

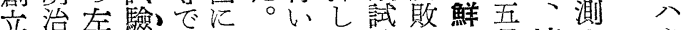

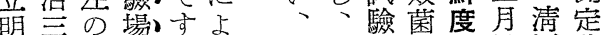

治示不学

四分5

十年な香

年十蓹川

七一返縣

月月事小

豆豆心碝

郡島た苗

立醉油き村

造組

試合しか

驗立たら

場釀。は

造場
現汹多保日酒法

在等上分持本酸

主向方離農稘昭

と菌てし

乙强て

て對力

乳しにリ

酸七腐 メ

菌抗敗于

類生能 ラ

に物をミ

質示ン

いを娄生

て生 バ成

有產》能

學菌和 昭

會對六和

比年

群る

表有月

效右 云

生發 文

物 表

質

分

分

生

酸 保 和 . 